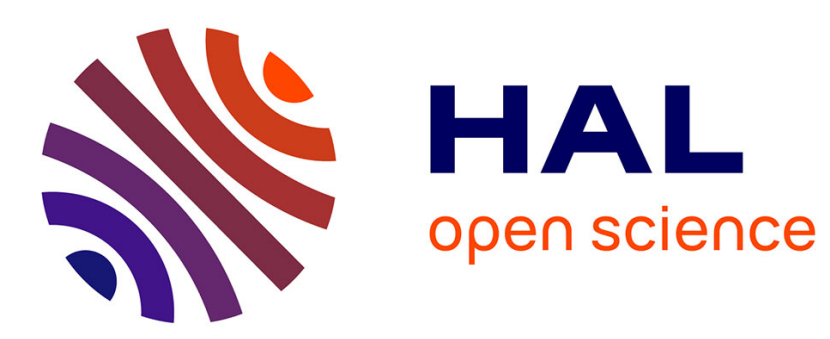

\title{
The Role and Utilization of International Academic Social Networks in Digital Publishing
}

Marina Bantiou, Arsenios Paxinos

\section{To cite this version:}

Marina Bantiou, Arsenios Paxinos. The Role and Utilization of International Academic Social Networks in Digital Publishing. ELPUB 2020 24rd edition of the International Conference on Electronic Publishing, Apr 2020, Doha, Qatar. 10.4000/proceedings.elpub.2020.7 . hal-02544228

\section{HAL Id: hal-02544228 \\ https://hal.science/hal-02544228}

Submitted on 16 Apr 2020

HAL is a multi-disciplinary open access archive for the deposit and dissemination of scientific research documents, whether they are published or not. The documents may come from teaching and research institutions in France or abroad, or from public or private research centers.
L'archive ouverte pluridisciplinaire HAL, est destinée au dépôt et à la diffusion de documents scientifiques de niveau recherche, publiés ou non, émanant des établissements d'enseignement et de recherche français ou étrangers, des laboratoires publics ou privés. 


\title{
The Role and Utilization of International Academic Social Networks in Digital Publishing
}

\author{
Marina Bantiou and Arsenios Paxinos
}

\section{Introduction}

1 Recognizing the importance of scientific content (monographs, journals, etc.) for the development of science and harnessing the potential of electronic media, it is necessary to create the conditions for the electronic publication of high quality scientific and technical books with open access. Social networks contain many features and applications being able to contribute to the scientific and academic community, being able to be a field for exchange of scientific knowledge by providing information. Social networking is defined as the practice of expanding knowledge by making connections with people with similar interests (Gunawardena, Hermans et al. 2009). The main parts of an online social network are four a) a place to upload a personal profile, b) connecting different members $\mathrm{c}$ ) the ability to follow your connections activities and d) the ability to establish new connections (Boyd \& Ellison, 2007). International Academic Social Networking (IASN) is a constant issue due to its dynamic evolution tending to consolidate as a new social phenomenon. It offers interactivity and direct interaction by reducing geographical distances offering opportunities for flexible, distance learning (Harasim et al., 1995). Social media encourage discussion, feedback, exchange and dissemination of information by all members (Roschelle \& Pea, 2002). Apart from that they define the democratization of information, as through its use, people become publishers of their content and do not remain only readers (Evans, 2008). This paper focuses on the issue of the role and utilization of IASN in digital publishing. The present study, through observational research and secondary quantitative and qualitative data analysis, aspires to examine and interpret the capacity of academic social networks to influence digital publishing, presenting both the advantages and the emerging limitations. The aim is to determine the relationship of social media with the academic 
community and digital publishing, while highlighting strengthens and weaknesses of existing academic platforms and discussing the licensing barriers that they emerge.

\section{Advantages and Limitations: The example of ResearchGate and Academia.edu}

2 The benefits of successful networking are varied, mainly by solving common problems, professional development and researcher's education, common benefit and empowerment of participants. ResearchGate and Academia.edu are the most comprehensive proposal for social networks, which are oriented in scientific research, as is evident by the extremely large number of users. According to statistics on its site, ResearchGate claims that it has over 15 million members (ReseachGate, 2020) and Academia.edu over 99 million existing members (Academia.edu, 2020). It should be mentioned that these sites are not an open access repository but platforms, used mainly by academic society. Researchers all around the world have the opportunity to create public or private profiles, publish their projects, exchange ideas and comments on their field changing the open access reality. These popular social networks allow their users to receive also statistical reports depending on the impact of their research work, and keep up to date with news and updates from scientific groups or independent researchers who have choose to follow. In this way, interaction, which is an important component (Bunus, 2010), collaboration, active participation, information, critical thinking (Selwyn, 2012) and activity support are achieved by highlighting new innovative forms of publishing. Researchers can exchange ideas, share information (DeSchryver et al., 2009), and work with anyone who has common interests, ideas, and needs. For example, each user could invite other users to a discussion about a specific monograph, get updates for changes or new additions related to their academic interests. IASN could aggregate articles chosen by a researcher, counting how often those articles are read connecting this researcher with compatible colleagues or additional monographs based on key words and information about previous article usage. This may help researchers begin conversations and collaboration with others interested in the same research. The real power of a community lies in the potential to collaborate, either within a known group or team or with unknown researchers (Cordis News, 2008). ResearchGate for example even encourages users to publish both successful results and negative data in order not to be repeated by other researchers. A researcher may set up also a research group with fellow collaborators. This has several positive benefits. First, those who are interested in a particular area may find additional resources more efficiently through these contacts. Second, researchers who conduct similar research may be identified. Collaboration may substantiate research findings quicker or expand those findings more efficiently and expeditiously. Third, through contact with other researchers, one may identify key questions for further research or research areas that have led to dead ends. A social network for university students, scientists, academics, and others who share the passion and the same research interests could build relationships, exchange ideas, find jobs and identify exciting new career opportunities. Universities and institutions are able to post position opening on these platforms. A community could help researchers work more efficiently offering a web service to organize, collect, and share scientific papers (Un. of Oklahoma). As an advantage of IASN we could say, that it 
allows members to participate in using hand-held devices like tablets, mobile phones and similar devices. The members from different countries have the ability to share their opinion and insights anytime using even their mobile phones. The author, without limitation as in printed books, may include his works in a digital community, as well as variations of his work, translations into other languages, unlimited enclosed accompanying and interpretive material as well as visual material such as manuscripts or photographs, maps, videos, and even audio files. IASN make it easy to search for information by directly identifying topics of interest to the user, which would not be possible in a wider social network (Price, 2007). In addition, networks can provide feedback for the open access system itself if members are enabled to actively monitor, respond to emerging needs, and co-manage, together with scientific staff, developments in research institutions, significantly speeding up the transfer of knowledge through digital publishing and opening new paths for cooperation and development of new research fields. Furthermore, it is possible to create various events concerning the scientific community, such as conferences, seminars and workshops for the purpose of being immediately notified to the members of the scientific community. Additionally, there is the possibility of sending a personal invitation. . Regarding selfpublishing there are authors who provide the electronic form of their books for free to readers in social networking sites. Self-publishing means that the author himself plays the role of editor, publisher, seller, and dispenser. ResearchGate and Academia.edu allow you to add information about yourself to your profile. Also, social networks give members the opportunity to use them as an online research oriented CV allowing to add information such as work and teaching experience, awards or prizes.

On the other hand the first main disadvantage is copyright infringement. Another thought with academic social networks is the legality of uploading a paper there. The majority of publishers require authors to sign a publishing or a copyright agreement before publishing a manuscript describing what they allowed to do with their work (Un. of Oklahoma). That means that uploading a paper to a site such as ResearchGate or Academia.edu may be in breach of contract terms. For example the academic publisher Elsevier BV in 2013 went actively after Academia.edu for copyright infringement, requiring them to remove 2,800 papers of the publisher's content that had been illegally uploaded (Solon, 2013). ResearchGate also had to remove nearly 7 million articles or about $40 \%$ of their content (Un. of Oklahoma) because of copyrights violations. In addition, it is important to note that some of these site tactics are worrying because of their involvement in privacy and intellectual freedom collecting information about who is reading what, etc. Academia.edu, in particular, even offers to share these information with the members if they sign up for a premium service, which is payable. The dashboard doesn't reveal the names of the readers but it can provide an insight in your readership to know exactly who is reading your work (Un. of Oklahoma). At the same time, there is a need for the social network administrator to constantly monitor for illegal material, which may be shared through the system without the publisher's or author's approval, violating their copyrights. An examination of randomly selected full-texts of 500 articles, which were posted on ResearchGate, demonstrated that only 108 (21.6\%) of these items were from open access journals and 51.3\% infringed the copyright and were non-compliant with publishers' policy (Jamali, 2017). Another issue with academic social networks is that a high percentage of their members are undergraduate or postgraduate students, which could be a drawback for established researchers (Evans, 2013). Finally, it should be mentioned 
that such as academic platforms are not accredited as educational institutions and their content does not mean it is always reliable, while paying attention as well to numerous false accounts, which lead to insecurity and, consequently, to the restriction of the use of social networks. Nevertheless a significant role in this, has the fact that ResearchGate and Academia.edu are mainly used by younger researchers and so often by established academics.

\section{Conclusions}

The social networks that have dominated everyday life have already gained the favor and attention of the academic community. In conclusion, it can be said with certainty that social networks improve and facilitate to some extent the work of both researchers and the wider academic community. The ease of searching among scientific articles and books and the interdisciplinary collaboration of scientists are among the main advantages. The global academic community could take advantage of the potential of social networks to keep up to date with developments in their science as well as to exchange ideas and opinions through a platform that facilitates direct communication between researchers and academics. The ability to collaborate through the web significantly contributes to increasing the speed of sharing a paper and also commenting on it, as it would traditionally take a long time for this to happen. Thus, a digital library of scientific articles and publications is created in this way, allowing members to directly search for the subject that concerns them, while also giving them the opportunity to write their opinion. The aforementioned positive elements of social networks they are also confirmed by a number of other studies referenced in the literature review. The goal is to make academic content of every age and every corner of the earth universally accessible to the public, regardless of where they live with the second goal of facilitating the spread of knowledge with dedication to transparency, the cultivation of creativity, the involvement of communities within and beyond open access. Of course, there are still many open issues in this new context, awaiting an answer or solution regarding to the barriers that arise in management of copyrights, since uploading in academic social networks could be illegal because of breaching publisher policies. It is very important for researchers to check the archiving policies for each publication before choosing to upload or share documents. The development and maintenance of research and cooperation networks is particularly important, because they establish democratic structures in humanities by enhancing the personality of each participant, educator or researcher. 


\section{BIBLIOGRAPHY}

Apostolou M., Antoniou P., \& Papastergiou M. «Online Learning Communities: An innovative learning environment for environmental education», Lionarakis A. (ed.), Proceedings of 5 th International Conference in Open \& Distance Learning, Vol. A, Part A, Athens: Hellenic Network of Open \& Distance Education, Hellenic Open University, The Open Education Journal, 2009, pp. 125-138.

Boyd D. M. \& Ellison N. B. «Social network sites: Definition, history, and scholarship», Journal of Computer-Mediated Communication, 13, 2007, pp. 210-230.

Bunus P. «The social network classroom». In: Lytras M.D. et al. (eds), Technology Enhanced Learning. Quality of Teaching and Educational Reform. TECH-EDUCATION 2010, Communications in Computer and Information Science, vol. 73, Berlin, Heidelberg: Springer Verlag, 2010, pp. 517-524.

Cordis News. «Virtual network benefits researchers». Available at https://cordis.europa.eu/ article/id/30144-virtual-network-benefits-researchers (20/03/2020).

DeSchryver, M., Mishra, P., Koehler, M., \& Francis, A. P. «Moodle vs. Facebook: Does using Facebook for discussions in an online course enhance perceived social presence and student interaction?», Proceedings of Society for Information Technology and Teacher Education International Conference, Chesapeake VA: Association for the Advancement of Computing in Education, 2009, pp. 329-336.

Evans D. Social Media Marketing: An Hour a Day, Wiley Publishing, 2008.

Evans J. «Review of ResearchGate: Pros and cons and recommendations, Open Research Exeter». Available at http://blogs.exeter.ac.uk/openresearchexeter/2013/11/06/74/ (20/03/2020).

Fortney K., \& Gonder J. «A social networking site is not an open access repository», Office of Scholarly Communication, University of California, 2015, https://osc.universityofcalifornia.edu/ 2015/12/a-social-networking-site-is-not-an-open-access-repository/ (20/03/2020)

Gunawardena C. N., Hermans B. M., Sanchez D., Richmond C., Bohley M. \& Tuttle R. «A theoretical framework for building online communities of practice with social networking tools», Educational Media International, 46:1, 2009, pp. 3-16.

Harasim, L., Hiltz, S., Teles, L., \& Turoff, M. Learning Networks: A field guide to Teaching and Learning Online, Cambridge: MIT Press, 1995.

Jamali H. R. «Copyright compliance and infringement in ResearchGate full-text journal articles», Scientometrics 112, 2017, pp. 241-254.

Roschelle J., \& Pea R. «A walk on the WILD Side: How wireless handhelds may change CSCL», Proceedings of the Conference on Computer Support for Collaborative Learning: Foundations for a CSCL Community Boulder, International Society of the Learning Sciences, 2002, pp. 51-60.

Selwyn N. «Social media in higher education», The Europa World of Learning 2012, 2012, Routledge.

Solon 0. «Elsevier clamps down on academics posting their own papers online», 2013, https:// www.wired.co.uk/article/elsevier-versus-open-access.

The University of Oklahoma, «Understanding Academia.edu and Researchgate», (n.d.) https:// libraries.ou.edu/content/understanding-academiaedu-and-researchgate 


\section{ABSTRACTS}

This paper focuses on the issue of academic social networks as means of changing the open access reality. Nowadays a free, direct and permanent access to digital scientific content is necessary for every student and researcher. The need for human communication has made social networks popular to the public, resulting in their rapid development, for example, ResearchGate and Academia.edu. The study is motivated by one main research question: What is their role and utilization in digital publishing? Through observational research and secondary quantitative and qualitative data analysis, the key objectives of the study are to highlight the role of international academic social networks in digital publishing and present the benefits and limitations of existing networks. In conclusion, the active use of academic social networks enables researchers to expand their knowledge but on the other hand limitations on digital publishing arise regarding to copyrights and licensing barriers.

INDEX

Keywords: social network, open access, international academic social network, digital publishing, electronic publishing

\section{AUTHORS}

\section{MARINA BANTIOU}

PhDC, Scholar of GRST \& HFRI

Department of History Ionian University Corfu, Greece

marina_badiou@hotmail.com

(corresponding author)

\section{ARSENIOS PAXINOS}

BSCE

Department of Civil Engineering Pegaso International, Smart City, Malta 